\title{
Analysis of the Interaction between Dividend Policy and Firm Performance in Manufacturing Sector
}

\author{
Shankar Kumar Singh Jha ${ }^{1}$, Usama Aziz ${ }^{2 *}$ \\ ${ }^{1}$ L. N. Mishra College of Business Management, Bihar, India \\ ${ }^{2}$ Government College University, Faisalabad, Pakistan \\ shank010460@gmail.com, *uaziz99@gmail.com
}

\begin{abstract}
The purpose of this study is to investigate internal determinant factors of dividend policy in manufacturing firms. The study considers the impact of dividend payout ratio, signalling, earnings per share and risk on firm performance. This research also tries to create a link between dividend policy and firm performance. In the same way, the research is also aimed to create a link between these factors. Such as, the current link between the dividend policy and firm performance. It will elaborate this through current and previous studies as a whole. This study used primary data from the listed manufacturing firms in order to check the effects of dividend policy on firm performance. Data was collected from the primary source. The survey questionnaire was used to collect data from top management in order to highlight the impact of dividend policy on firm performance. Multi-regression analyses were undertaken to identify attributes that influence dividend policy. The results of the study demonstrate that all the variables are significant thus they have a positive impact on firm performance. The study established the findings that dividend payout, earning per share, signalling and risk positively and significantly influence the firm's value. Moreover, companies should consider dividend policy in order to make the financial decision more efficiently. This study tells us that decisions about dividend policy should be made by considering other variables. The study has both practical and theoretical implication for top management in order to consider the dividend policy and its impact on firm performance.
\end{abstract}

Keywords: Dividend policy, payout ratio, signalling, risk, earning per share

\section{Introduction}

Dividend policy is a return to investors and is also a mechanism worn to alleviate organization problems in a manufacturing company, usually through bulky possession (Useem, 1993). Dividend policy is claimed to be one amongst the crucial apparatus of a firm's policies and has been viewed as an important matter in the literature (Myers, 1977). Dividend policy is one amongst the companies' choices that area unit originated to be prejudiced by ownership structure (Jensen, 1993). When countries have deficient funds, they may route to internal and external borrow to attain unsure goals (Krugman, 1999) (financing public expenditures, preventing inflation, etc.). Developing countries, in particular, are facing deficiencies to achieve economic growth in order to boost up their income and production (Korkmaz, 2015). Dividends are often used to solve agency issues in the corporation. On the opposite hand, large shareholders may use their power to steal community resources for their own personal use. The corporation earns the yield to assign among stockholder what is more on an annual basis, seminally basis or quarterly basis or no dividend, it depends upon the corporate management choices. Its altogether depends upon the management of the corporate. Dividend is understood as a puzzle within the field of finance for quite half a century. Ranging from the (Miller and Modigliani 1961) discussion on the dividend connectedness to the firm's performance.

Numerous arguments are offered within the connection of dividends to the firm performance and lack of it as well. However there's still discussion among the researchers (Sakr, \& Youssef, 2016). The dividend policy has been a controversial subject since the introduction of the theory of the irrelevance by (Miller and Modigliani 1961). In spite of several decades of research on the thought of dividend, questions stay without an answer. "Although a number of theories have been put forward in the literature to explain their pervasive presence, dividends remain one of the thorniest puzzles in corporate finance" (Dalton, Janes et al. 2002). Dividend policies are claimed to be one in all the foremost vital subjects and analysis topics of finance. Yet, the question of what are the determinants of the dividend policy seems to be unsolved. In Pakistan, Karachi Stock Exchange (KSE) is the major and the most seasoned stock trade, which is computed through KSE-100 record. KSE has made numerous accomplishments and is considered as a top exchange in the term of performance around the world. But its performance is not good over the last few years (IMF Country Report, 2013). Delisting of 110 companies is done by KSE for last few years because they are not paying a dividend on a regular basis (Muneer, 2015). 
Dividend policy is a serious issue from many decades, but no generally accepted explanation from the companies about dividend policy has been observed (Peggs, et al. 2011). Dividend policy has been determined for various decades, however not a solid argument put together to the established description for companies' experimental dividend performance has been recognized (Peggs, et al. 2011). Objectives of the study are to find out how the dividend policy is being practiced among the manufacturing firms of the Faisalabad. This is also focused on factors used to find out the effect of dividend policy on firm performance. This study focuses on the impact of payout ratio, signalling, earning per share and the impact of risk on firm performance (Hunjra, et al, 2011). The main focus of this study is to find out the factors that what are the policies of dividend policy is being followed by manufacturing companies (Miller \& Rock, 1985). It also studies that what is the empirical relationship between dividend policy and firm performance is being perceived (Aupperle, et al, 1985). The last but not the least factor is that is there any effect of earning per share, signalling, dividend payout ratio and risk on dividend policy that affects the firm performance. While studying about the dividend policy we are focusing on the issue that is there any connection between dividend policy and firm execution in manufacturing companies (Bhattacharya 1979). As we realize that profit approach is first perceived as a substantial angle in an organization's stock esteem (Brav, et al, 2005). However, numerous analysts are in a view that in the corporate sector, dividend policy should not matter in a firm's stock value.

\section{Literature Review}

Dividend policy belongs to a set of rules or norms which the firm follows in order to decide how much of profit it will pay-out to shareholders (Gamba \& Triantis, 2008). The foremost objective of any organization is to boost up the values of its shares and its investors (Lazonick \& O'sullivan, 2000). Here we are going to study the effect of dividend policy on firm performance with respect to other factors like the dividend payout ratio, earning per share, signalling and risk. "The harder we try to understand the dividend decisions by the firm, the more it seems like a puzzle, with pieces that just do not fit together" (Lamyaa and Karima).

Agency Theory: Exists when the standards which are unable to supervise his business on his/her delegates the authority to the negotiator (Jensen \& Meckling, 1976). Dividends may be used in order to minimize the organizational cost. Agency problem merely refers to the principal-agent problem where the holder of the stock is principle or shareholder and agent is the manager. The theory of agency is helpful in solving the principle and agent issues with the aim of ensuring a better relationship between them (Nwidobie, 2013).

Bird-In-Hand Theory: Developed this theory, stating dividends are associated with companies' price (Gordon, 1962). The model developed by the Gordon is determinants of the price of equity are a future dividend, this share value and therefore the rate of growth. Consequently, dividend yield and growth provide a return to holders of equity. This whole development comes with a theory of dividend called bird-in-hand theory (Nizar Al-Malkawi, 2007).

Tax-Preference Theory: Shows that in the long-standing time, preserved earnings end up in capital gains, Capital gains are taxed at a lower rate than the dividend. Hence, taxation is a vital thought for investors. Thus investors could like capital gains to dividends. This can be remarked because of the "Tax-Preference theory" (Litzenberger and Ramaswamy, 1979).

Dividend Signaling Theory: Is predicated on the particular data whom managers have higher approach than that of outer shareholders, to the inner data of the corporate (Eckbo \& Verma, 1994). They'll signal such data with the shareholders and potential investors through their dividend policy so as to cut back asymmetries.

Dividends Irrelevance Theory: Miller and Modigliani (1961) indicate that dividend policy is irrelevant in deciding the worth of the firm. The idea is advocated by a bunch of economic theorists (Holder, et al. 1998). A firm's dividend policy may minimize problems among shareholders and managers in order to boost up firms' value towards shareholders. Dividends are a way to mitigate the organizational performance where managers may use the extra cash in order to chase their own interest. Dividend costs convince the organization to enhance funds externally for new opportunities, resulting in this the level of monitoring external activities remains in focus (Jiraporn, et al. 2011). 
H1: There is a significant effect of dividend payout ratio on the firm performance. Earnings per share are the part of company's surplus to be paid to every outstanding share. Company's profit divided by its variety of common outstanding shares is solely outlined as earning per shares. Earnings per share are a suggestive financial gain that earns every usual share and often wont to measure the productivity and risk coupled with profit. The study shows that there's a vital relationship between earning per share and firm performance. Analysis hypothesis investigates the effects of return on equity and earnings per share (Yazdanfar, \& Öhman, 2015).

H2: There is a significant effect of earning per share on firm performance. The risk is outlined as something which will produce hindrances in order to achieve some objectives. Organization performance has been the foremost vital issue for each organization. It's important for managers to understand what factors influence an organization's performance so as to require applicable steps to initiate those factors. The risk and revisit are directly linked with one another, it means that if one will increase than other will obviously increase. And, effective risk management results in a lot of balanced trade-off between risk and reward, to understand an improved position within the future. Globalization and internationalization have increased the risk of firms in developing countries. This is due to competition from within and outside the countries by either directly from other or indirectly through access to International trade (Klassen \& McLaughlin, 1996). Lots of work done in the field of pay-out ratio but still there are lots of flaws in this sector so we did research in order to have a deep study of these factors. The hypotheses of dividend payout ratio are to check its relation with firm performance.

H3: There is a significant effect of risk on firm performance. The dividend-signalling is one among the key problems with the sector of company finance; maybe no alternative space of finance has been subject to most empirical investigation throughout the last 5 decades because the behavior of stock costs in reference to dividend announcement. Therefore, an effort has been made to review previous studies conducted in developed countries of the globe also as in rising markets. Once a corporation announces a rise in dividend payouts, it's a sign it possesses positive future prospects this is often referred to as signalling. The number received as dividends depends upon the number of shares one holds. Dividend signalling features a nice impact on firm performance. Managers of the firm will amend the expectations of individuals with regards to its future earnings through dividends Gilley \& Rasheed, 2000).

H4: There is a significant effect of signalling on firm performance. The overview of dividend policy is presented in this chapter. It provides the differences of relevance and irrelevance theory based on the dividend. Dividend policies adopted in practice are also discussed in this chapter. As in the start it has been elaborated that the main objectives are to identify the effect of dividend policy on firm performance. In start review of the literature was presented based on firm performance and find out the gap to support the hypothesis as well as a model of the study was developed. The summary of this study is to view again the existing theories supported dividend policy and their findings.

\section{Figure 1: Framework}

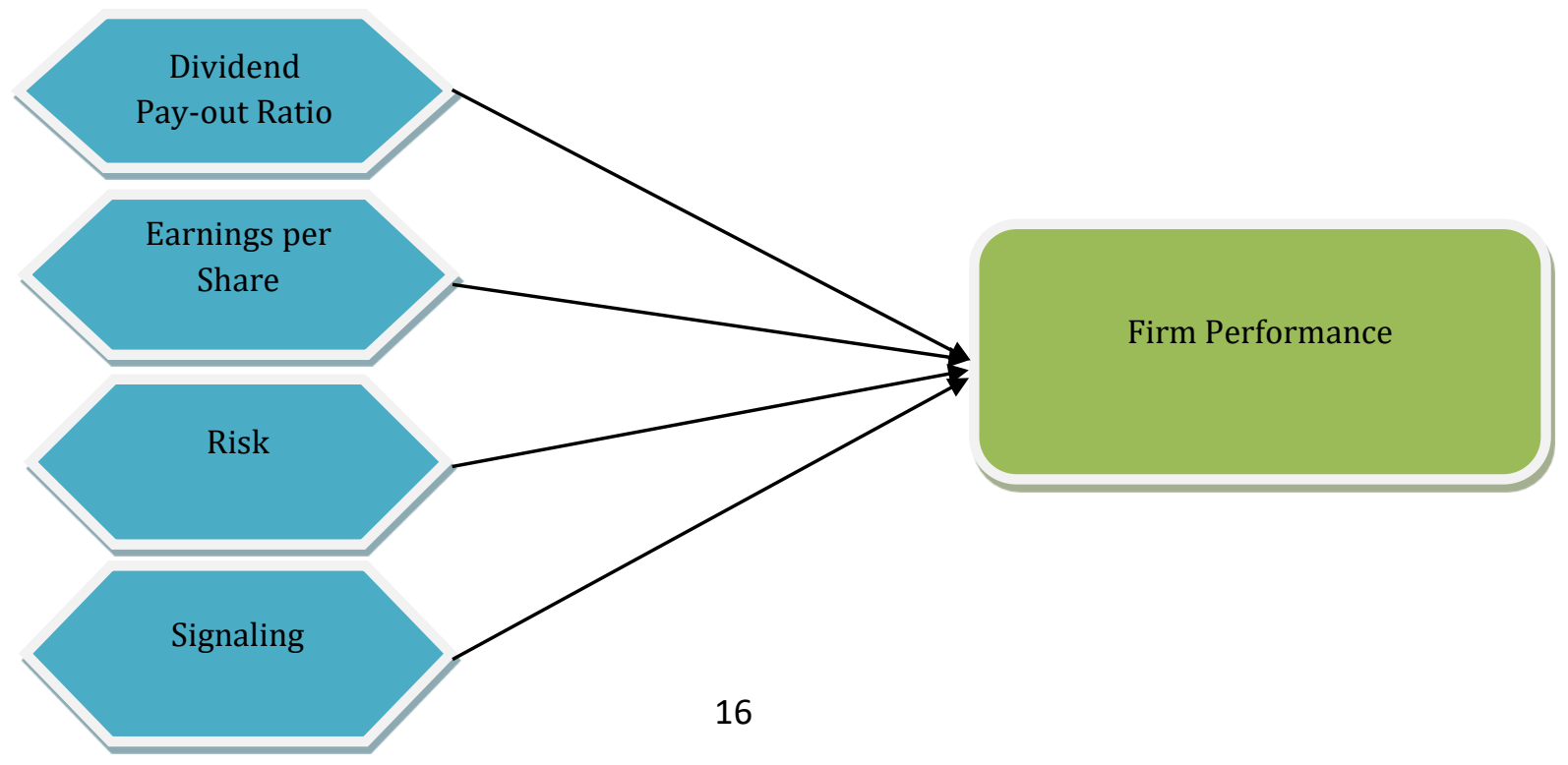




\section{Methodology}

This section concentrates on the different parts of research philosophy. Reconsider the applicable writing on dividend policy. The discussion is that whether shareholders want to invest in the organization with those dividend payments or to whom those who never pay the dividend. Researchers put forward the studies and come with complete diverse markets. Management of the company decides whether to pay a dividend in the form of cash or in the form of capital gains. This depends upon the company's repute in the market. Essential information is utilized to shape the reason for examination. The yearly money related report together with organizations' profiles and points of interest of greater part investors are altogether shown on the site of organizations. The assembling organizations incorporate Textile, Automobile, Cement, Chemical, Engineering, Food and Telecom. Top management of the organization is the target population. We use to gather information from the best administration which consists of Executive director finance, senior chief Manager Finance, AVP finance and Manager Share. Sample size of our research is manufacturing firms from where we used to take feedback in the form of a questionnaire. We sent a questionnaire towards 350 listed firms. This sample size is supported by (Comrey \& Lee, 1992) which suggested a criterion about sample size: 100=poor, $200=$ fair, $300=$ good, $500=$ very good \& 1,000 or more=excellent. Coming about to that we got 130 filled questionnaires. Identification of variable is evidence that somewhat doubtful step utilized as a part of the research. In any case, once you acknowledge it, you will be on the safe side. Here we used to distinguish our variable in view of research profit strategy having its consequences for firm execution in general. Our dependent variable (DV) is Firm performance and Independent factors (IVs) are Target payout ratio, Signaling, Risk and Earning per share.

Dependent Variable: A variable that will be clarified or expected. As, this examination explores the connection between money related practices and execution of the firm, and by large the execution accepted as a dependent variable. Eventually, it is impractical to measure implementation simply since it is an inactive word. This is a kind of variable that has its great impact on independent variables. Dependent variable has its impact on firm performance the norms and policies of the organization very much affected by the dependent variable.

Independent Variables: which are included in this study, related to firm performance independent variables are directly related to Dependent variables. They have deep effects on firm performance with respect to dependent variables. The independent variable is a variable that has an effect on the dependent variable (Kroupa, et al. 1997).

Table 1: Sample Description

\begin{tabular}{lll}
\hline S. No. & Industry Name & Response Rate \\
\hline 1 & CEMENT & 13 \\
2 & AUTOMOBILE & 7 \\
3 & SERVICE & 2 \\
4 & CHEMICAL & 18 \\
5 & FOOD PRODUCTS & 12 \\
6 & OIL \& GAS COMPANIES & 1 \\
7 & TEXTILE & 79 \\
\hline
\end{tabular}




\begin{tabular}{llc}
\hline 8 & FERTILIZER & 43 \\
9 & PHARMACEUTICALS & 34 \\
10 & TELECOM & 21 \\
11 & SUGAR & 2 \\
12 & ENGINEERING & 6 \\
\hline
\end{tabular}

\section{Results and Discussion}

The main objective of the current study is to identify factors that influence dividend policy in a sample of manufacturing companies listed on KSE. Next step was to find out dividend payout ratio of list firms in Exchange. The next step was to calculate the dividend of the listed manufacturing firms. This can be calculated in two main ways. The first step relates to the dividend paid during the specific period of time. The second step based on dividend income and its distribution. Several variables used in this in this study like dividend payout ratio, earning per share, signalling and risk. This chapter will give details of all variables employed in the current study together with regression analysis. The data collected through a questionnaire. Then different statistics have been applied to analyze the data. The descriptive statistics used to evaluate major indices and demographic indicators of the questionnaires included frequency distributions, percentages, and charting inferential statistics calculate data after it coded to determine the descriptive indicators.

To answer the study and checking the hypotheses of the study, parametric statistical tests employed. Research questions and objectives linked with the findings of the study, which presented in this chapter. This is a basic assumption that the model of the equation and structural analysis should be normalized (Hooper, Coughlan et al. 2008). There are many ways to check data are normal or not, but here in this study P-P plots are used as this is considered as the best method in order to have research of large sample size (Hair, Sarstedt et al. 2012). Figure 4.1 shows the residual histogram for dividend policy and firm performance. Figure 4.1 is just like the bell-shaped curve and major frequency scores fall within this bell. This shows that the data is normally disbursed. Beside this, P-Plots used to check outlines of multivariate analysis with the help of observed outcomes. In this P-Plot higher and lower residual is being checked. Figure 4.2 identifies that the variable's standardized residual is normal.

The researcher used PLS-SEM, a non-parametric approach (Eagly and Chin 2010). While, the non-parametric approach of statistics is not in a position to demand that should be normal data yet normality test is implemented in order to capture the more accurate results. The explanation subsequent to this is that normality is measured as the base for descriptive information, whether the approach is both non-parametric or parametric (Yu, Goh et al. 2014). Normality is the belief that explains each variable that is based on combinations of variables are commonly distributed. The Statistic value of kurtosis and Skewness should be fall within \pm 2.00 (Bolker, Brooks et al. 2009). The subsequent table demonstrates the Skewness and kurtosis values of the study variables. The final model of the research shows the summary of calculated values of data from SPSS software. The value of $\mathrm{R}$ is being calculated which is .868, and the value of $\mathrm{R}$ Square is .754 . As we know that the value of $\mathrm{R}$ Square should be in between 0.5 to 0.8 then it will consider as an acceptable value.

Table 2: Model Summary

\begin{tabular}{lllll}
\hline Model & $\mathbf{R}$ & R Square & Adjusted R Square & Std. error of the Estimate \\
\hline 1 & $.868^{\mathrm{a}}$ & .754 & .746 & .23768 \\
a. Predictors: (Constant), Earning PS, Target PR, Signaling T, Dividend MS & \\
\hline
\end{tabular}


Table 3: ANOVA

\begin{tabular}{|c|c|c|c|c|c|c|}
\hline Model & & Sum of Squares & DF & Mean Square & $\mathbf{F}$ & Sig. \\
\hline & Regression & 21.490 & 4 & 5.373 & 95.103 & $.000^{\mathrm{b}}$ \\
\hline \multirow[t]{2}{*}{1} & Residual & 7.005 & 124 & .056 & & \\
\hline & Total & 28.495 & 128 & & & \\
\hline
\end{tabular}

The ANOVA findings on table 4.10 show that the regression model is significant and is considered as a good predictor of the relation between dividend policy and firms' performance. This is because the $\mathrm{F}$ statistics value of 95.103 is significant at $5 \%$ level of significance as $P$ value $0.000<0.05$. Examining the effect of dividend policy on firm performance using a multivariate regression model, that illustrates the relationship of dividend policy and firm performance. The result shows that attention should be paid to the factors of dividend policy in order to check the effect of it on firm performance. Here we have Adjusted R Square that is 746 and standard error of estimate is 0.23678 . So this shows the validity of the Model. The study suggested that the performance of listed firms in KSE can be boosted up by using the dividend policy effectively. To check the effects of indirect variables on direct variables, a method of linear regression is being used here.

\section{Conclusion}

Chapter five is based on a summary of this research, conclusion, recommendations, limitations and suggestions of the study. This is basically based on the area that is required for more concern for further study. This chapter presents the outline of findings of this analysis, conclusions, recommendations, and limitations of the study with the suggestion of areas which can need more thought. Dividend policy is considered as the important part of corporate financing. As we know that the dividend policy influences the financing decisions. This study is based on the dividend policy and its impact on manufacturing firms of Faisalabad listed on KSE. This study has some kinds of limitations that must be overcome in order to make the research better in future. Access to some important aspect of the research must be the focus in near future. Lack of funds, information and other important resources are the certain limitations of the research that must be the focus in order to make the research better in future. Similarly, due to insufficient resources, the study uses the non-probability (purposive sampling) sampling technique and select 350 firm for the survey based on the dividend payment.

More time and funds are given because this population would increase to 600.Lacks of necessary things are the main limitations of the research. In consequence, data collection was only provided from primary data related to firm performance while the secondary data was not obtainable for this research study. This study has shown the effect of dividend policy on firm performance. This study recommends some points for further research for the researcher. This study is based on firm performance and dividend policy only, might lead to extended research to the huge businesses, state and overseas companies in Pakistan. The factors that are affecting the firm performance are of great importance. The researcher should focus on the vast area not only some specific manufacturing firms in order to go through better results in future. Impact of the relationship between capital structure decisions and firm performance could be tested in different industries or in a large sample size. The researcher should go and have research in developed countries like USA, Russia and China etc. in order to fetch the better results in future. 


\section{References}

Aupperle, K. E., Carroll, A. B. \& Hatfield, J. D. (1985). An empirical examination of the relationship between corporate social responsibility and profitability. Academy of Management Journal, 28(2), 446-463.

Bhattacharya, S. (1979). Imperfect information, dividend policy, and" the bird in the hand fallacy. The Bell Journal of Economics, 259-270.

Bolker, B. M., Brooks, M. E., Clark, C. J., Geange, S. W., Poulsen, J. R., Stevens, M. H. H. \& White, J. S. S. (2009). Generalized linear mixed models: a practical guide for ecology and evolution. Trends in ecology \& evolution, 24(3), 127-135.

Brav, A., Graham, J. R., Harvey, C. R. \& Michaely, R. (2005). Payout policy in the 21st century. Journal of financial economics, 77(3), 483-527.

Comrey, A. L. \& Lee, H. B. (1992). Interpretation and application of factor analytic results. Comrey AL, Lee HB. A first course in factor analysis, 2.

Dalton, J. S., Janes, P. A., Jones, N. G., Nicholson, J. A., Hallam, K. R. \& Allen, G. C. (2002). Photocatalytic oxidation of NOx gases using TiO2: a surface spectroscopic approach. Environmental Pollution, 120(2), 415-422.

Eckbo, B. E. \& Verma, S. (1994). Managerial share ownership, voting power, and cash dividend policy.

Gamba, A. \& Triantis, A. (2008). The value of financial flexibility. The Journal of Finance, 63(5), 2263-2296.

Gilley, K. M. \& Rasheed, A. (2000). Making more by doing less: an analysis of outsourcing and its effects on firm performance. Journal of management, 26(4), 763-790.

Gordon, M. J. (1962). The savings-investment and valuation of a corporation. The Review of Economics and Statistics, 37-51.

Holder, M. E., Langrehr, F. W. \& Hexter, J. L. (1998). Dividend policy determinants: An investigation of the influences of stakeholder theory. Financial management, 73-82.

Hunjra, A. I., Bilal, M., Shafi, H., Khokhar, I. U. \& Rehman, K. U. (2011). Patterns of capital structure and dividend policy in Pakistani corporate sector and their impact on organization performance.

Jensen, M. C. (1993). The modern industrial revolution, exit, and the failure of internal control systems. The Journal of Finance, 48(3), 831-880.

Jiraporn, P., Kim, J. C. \& Kim, Y. S. (2011). Dividend payouts and corporate governance quality: An empirical investigation. Financial Review, 46(2), 251-279.

Klassen, R. D. \& McLaughlin, C. P. (1996). The impact of environmental management on firm performance. Management Science, 42(8), 1199-1214.

Korkmaz, S. (2015). The relationship between external debt and economic growth in Turkey. Proceedings of the Second European Academic Research Conference on Global Business, Economics, Finance and Banking (EAR15Swiss Conference) ISBN.

Krugman, P. (1999). Balance sheets, the transfer problem, and financial crises. In International finance and financial crises (pp. 31-55), Springer, Dordrecht.

Kroupa, J., Vaněk, P., Krupková, R. \& Zikmund, Z. (1997). Dielectric and optical properties of weak ferroelectric cyclohexan-1, 1'-diacetic acid. Ferroelectrics, 202(1), 229-234.

La Porta, R., Lopez-de-Silanes, F., Shleifer, A. \& Vishny, R. W. (2000). Agency problems and dividend policies around the world. The journal of finance, 55(1), 1-33.

Lazonick, W. \& O'sullivan, M. (2000). Maximizing shareholder value: a new ideology for corporate governance. Economy and society, 29(1), 13-35.

Miller, M. H. \& Modigliani, F. (1961). Dividend policy, growth, and the valuation of shares. The Journal of Business, 34(4), 411-433.

Miller, M. H. \& Rock, K. (1985). Dividend policy under asymmetric information. The Journal of finance, 40(4), 1031-1051.

Muneer, S. (2015). An Interaction Between Financial Practices and Firm Performance with Moderating Effect of Agency Cost in Pakistani Corporate Sector, Universiti Teknologi Malaysia.

Myers, S. C. (1977). Determinants of corporate borrowing. Journal of financial economics, 5(2), 147-175.

Nenova, T. (2003). The value of corporate voting rights and control: A cross-country analysis. Journal of Financial Economics, 68(3), 325-351.

Nizar Al-Malkawi, H. A. (2007). Determinants of corporate dividend policy in Jordan: an application of the Tobit model. Journal of Economic and Administrative Sciences, 23(2), 44-70.

Nwidobie, B. M. (2013). Bank mergers and acquisitions and shareholders' wealth maximization in Nigeria Journal of Applied Finance and Banking, 3(3), 255-270. 
Peggs, K. S., Thomson, K., Samuel, E., Dyer, G., Armoogum, J., Chakraverty, R. \& Lowdell, M. W. (2011). Directly selected cytomegalovirus-reactive donor T cells confer rapid and safe systemic reconstitution of virusspecific immunity following stem cell transplantation. Clinical infectious diseases, 52(1), 49-57.

Sakr, A. \& Youssef, N. (2016). The Effect of Corporate Governance on Mutual Fund Dividend Policy: Evidence from Egypt.

Useem, M. (1993). Executive defense: Shareholder power and corporate reorganization. Harvard University Press.

Yazdanfar, D. \& Öhman, P. (2015). Debt financing and firm performance: an empirical study based on Swedish data. The Journal of Risk Finance, 16(1), 102-118.

Yu, D., Goh, K., Wang, H., Wei, L., Jiang, W., Zhang, Q. \& Chen, Y. (2014). Scalable synthesis of hierarchically structured carbon nanotube-graphene fibres for capacitive energy storage. Nature Nanotechnology, 9(7), 555. 